\title{
AN EPIDEMIC OF ENTERIC FEVER SPREAD BY PERSONAL INFECTION IN AN ASYLUM.*
}

\author{
BY \\ L. BARD, \\ AND \\ M. PEHU, \\ Professor of Clinical Medicine in the \\ University of Geneva. \\ Tutor in the Faculty of Medicine.
}

THe question as to whether or not it is safe to treat cases of enteric fever in the wards of a general hospital has been the subject of much discussion in times past. About the year 1850 in particular the controversy was very sharp, and the profession in France was divided into two parties-those who were of opinion that enteric fever could be communicated directly from person to person, and those who opposed this view. Careful inquiry into outbreaks limited to families or in small villages led Leuret, Piedvache, and others, to the former conclusion.

In our own day, aided by bacteriology, we look upon water as the source of almost all the epidemics of enteric fever. There are some, indeed, who consider that water is the sole medium by which the specific organism is conveyed ; but so many cases of direct infection both in hospital and outside practice have now been recorded that no one can now refuse to believe that personal infection plays at times an active part in the propagation of this complaint.

As a matter of fact, the number of patients who contract enteric fever in a hospital is very small, and in the cases recorded the infection extendèd only to patients occupying beds in the immediate vicinity of enteric fever patients. In an exceptional instance mentioned by M. Pauly, an epileptic patient contracted enteric fever from a patient whose bed was some distance away, but the epileptic had not been confined to bed, and had, moreover, on several occasions attended upon the enteric patient. It is more common to find that those who are attending upon enteric patients contract the disease. M. Pauly quotes from a number of writers to show the relative frequency of secondary cases occurring in hospital. Thus, Murchison stated that in fourteen and a half years' experience at the London Fever Hospital only 8 cases out of a 'total of 2,506 cases were attributable to direct infection in the hospital. Steger ${ }^{2}$ places 44 cases out of 2,193 in this class, Liebermeister 45 out of 1,900 cases treated in the hospitals of Greifswald,

* From an article in the Revue d'Hygiène, tome xxii., No. 5, p. 410, May 20th, 1890, transiated by F. J. A. 
Berlin, Tübingen, and Bâle from 1865 to 1891; and Wernich 2 out of 225 cases. Nearly all those affected were nurses, or persons who had been watching or attending patients suffering from the disease. In none of these records is there anything approaching an epidemic such as was developed in the Bron Departmental Asylum during the summer and part of the autumn of 1898, when there occurred thirty-five cases between each of which we were able to trace direct connection.

This asylum for the insane, situated in the suburbs of Lyons, had at the date of the outbreak about 800 inmates, and a large staff of male and female nurses. The inmates themselves also frequently assisted the nurses in their work.

The asylum is divided info two wings, each consisting of nine blocks. One wing is reserved for male patients, the other for the female, and between the two is the administrative block. The water-supply to the asylum was obtained in 1886 from a source situated some distance off on higher ground. The water is pumped into reservoirs near the village of Bron. From these reservoirs the water descends by one pipe, which divides near the central block into two branches to supply the two principal divisions of the asylum. A pipe is taken off for each block, and carries water to a tap over a sink, and to ten or twenty lavatory basins. The administrative block alone is provided with Chamberland filters.

Enteric fever appeared in the female wing of the asylum at the end of June, 1898, and continued until the end of November. With one exception, the cases were restricted to persons connected with this wing. There had been no outbreak of enteric fover in the adjoining village of Bron, but a severe epidemic prevailed in the town of Lyons from June onwards, where enteric fever usually occurs during the same period every year. The existence of the disease in the district from which the asylum draws its patients suggested the probable origin of the outbreak. Before, however, dealing with the origin and cause of the outbreak, it may be well to record the cases in chronological order :

1. P., female patient. Entered asylum December 15th, 1895. First symptoms of enteric fever noted June 29th, 1898; eruption of rosecoloured spots July 2nd; recovery August 7th; left asylum November 10th, 1898. This patient had been formerly in Division 2, and was moved to the infirmary of Division 7 in May, 1897. Origin of disease unknown.

2. G. P., female patient. Entered asylum (Division 7) May 6th, 1898. Beginning of disease August 9th, 1898; no spots; diarrhcea was severe, with much abdominal pain, high temperature, loss of conseionsness; death took place August 15 th ; no post-mortem examina- 
tion. Before this illness the patient had slept in the infirmary of Division 7.

3. G. S., nurse, usually attached to Division 8; appointed March, 1894. Date of last leave of absence August 5th, 1898. Taken ill August 7th; recovery at end of nineteen days. Had been on duty in Division 7 fifteen days before the first symptom appeared.

4. T. A., male attendant employed generally in the asylum; went out every day from five to ten p.m. Beginning of illness August 14th ; sent to hospital August 22nd; recovery September 27 th.

5. M. T., male attendant; appointed January 19th, 1898. Employed in the infirmary of Division 9; accompanied inmates to the kitchengarden. Beginning of illness August 16th; admitted to hospital August 22 ; discharged cured October 30 th.

These two male attendants appear to have been infected at the same time. They frequently went out together.

6. R. M., female patient. Entered asylum August 18th; stayed eight days in Division 4, and was then passed on to the clinical infirmary in Division 3. This patient was suffering from enteric fever on admission; spots had appeared, and there was a temperature of $102.9^{\circ} \mathrm{F}$. Cured August 6 th $($ sic) .

7. J. F., female patient. Admitted to the asylum February 12th, 1898 ; beginning of illness August 19th; rash 26th. Up to August 9th she had been in the infirmary of Division 7 with Cases 1 and 2. After that date she was sent to the clinical infirmary; recovery September 17 th.

8. D. A., female patient. Admitted to the asylum August 19th, 1892; entered infrmary of Division 7 August $20 \mathrm{th}, 1898$; rash August 25th. This patient slept at first in Division 8 , which adjoins the infirmary of Division 7 , and assisted the nurses there, carrying foecal and other discharges from the first to the ground floor. The nurses generally deputed this work to the inmates.

9. C. M., nurse. Appointed January 25th, 1898, in Division 4; date of last leave of absence August 17th, 1898 ; taken ill August 25th; sent to hospital August 26th ; died September 7th. On special duty from July 7 th to August 5 th in Division 4.

10. V. L., nurse. Appointed Angust 1st, 1897; was engaged in Division 3 (clinical). Date of last leave August 8th; taken ill August 26th; sent to hospital August 29 th ; discharged Oetober 2 nd. Probably infected from cases already in the division.

11. D. J., an idiot girl aged seven years. Admitted to asylum July 9th, 1898; always in Division 3 . Beginning of fever August 26th, 1898 ; rash September 1st; recovery September 20th. She slept in the infirmary, and her bed was close to that of Case 6 .

12. D. J., female patient aged nineteen years. Admitted to asylum October 9 th, 1888; was under treatment in the clinical infirmary from June 9th, 1898 ; beginning of fever September 1st; rash September 7 th; recovered September 24 th.

13. C. P., female patient aged twenty-seven years. Admitted August 17th, 1898; admitted to infirmary of the Clinical Division; beginning of fever September 1st; - rash September 5th; patient removed from asylum by her mother September 8 th. She slept on the ground floor in a private ward adjoining the Clinical Infirmary.

14. B. M., nurse, aged twenty-five years. Appointed March 15th, 1898, and was ordinarily attached to Division 9. Date of last leave of absence September 5th; beginning of fever September 6th; sent to 
hospital September 7th; recovery October 30th. Acted as nurse in Division 4 from July 21st to August 16th.

15. J., female patient. Admitted August 9th; beginning of illness not precisely known; admitted to Division 7 infirmary September 7 th; died September 11th. This patient had usually slept in infirmary.

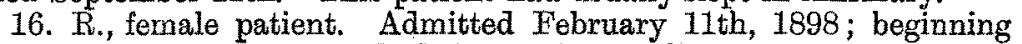
of fever September 7th; died September 10th. Was an inmate of Division 7.

17. L. C., male attendant, aged twenty-seven years. Appointed February 10th, 1897 ; beginning of illness Septernber 9 th ; sent to hospital September 11th; discharged November 12th. Was employed in the laundry, where he handled the linen of the fever patients.

18. N. M., female patient. Admitted May 5th, 1898; beginning of illness September 10th. In Division 4 up to that date; on September 14th sent to Division 7 ; recovered October 1 st.

19. D., female patient. Admitted April 30th, 1898 ; taken ill September 12th; recovered October 19th. This patient had been located in a private ward, where paying inmates only were received. These, however, received frequent visitors, who sometimes brought presents of articles of food.

20. P., male patient. Admitted April 26th, 1896 ; beginning of illness September 15th; recovery October 25 th. This patient belonged to Division 8 (male side), which is placed quite close to the infirmary where the two male nurses (Cases 4 and 5 ) were treated. He had been in frequent contact with them before their illness, and during it he assisted the nurses in charge of these two patients. This was the only case among the male inmates.

21. C. F., female patient, thirty-nine years of age. Admitted May 17th, 1898; beginning of illness September 15th; rash September 21 st; recovery October 7 th. Had been in the clinical infirmary (Division 3).

22. J. M., female patient. Admitted September 3rd, 1898; taken ill September 16th; recovery October 29th. Belonged to Division 4, in the infirmary of which she usually slept. On November 25 th she was sent to Division 7 .

23. D. J., nurse, aged twenty-one years. Appointed November 22nd, 1897 ; date of last leave September 16th; beginning of illness September 20th; sent to Nurses' Infirmary September 22nd; discharged October 18th. Was on duty in Division 4 from August 24 th to September 12th. There were several cases in this division during that period.

24. B. L., nurse, aged twenty-six years. Appointed November 22nd, 1897. On duty in the infirmary of Division 9. Last leave September 20th; taken ill September 21st, and was sent to Nurses' Infirmary September 22nd; died October 13th. This nurse attended upon Cases 10 and 14 .

25. B. A., female patient. Admitted May 13th, 1898; beginning of illness September 23rd; at first in Division 4, afterwards in Division 7 ; died October 6th. She frequently slept, as did other of the cases mentioned, in the infirmary of the division to which she belonged.

26. D. A., male attendant, aged thirty-six years. Appointed January $25 \mathrm{th}, 1889$; usually on duty in Division 1 (male side); taken ill September $27 \mathrm{th}$; recovery October $28 \mathrm{th}$. It was his duty to superwise inmates engaged in outdoor work, gardening, etc.

27. S., female patient. Admitted May $10 \mathrm{th}$, 1896; beginning of ill- 
ness October 2 nd ; rash October 6th ; recovery November 2nd. Slept frequently in Division 7 infirmary.

28. V. A., laundryman, aged twenty-three years. Entered service of asylum. July 13th, 1898; taken ill Ootober 9th; sent to hospital October 9th; discharged November 16th. This patient handled the soiled linen of the enteric patients.

29. D., female patient. Entered asylum August 21st, 1898; took to bed October 6th; rash October 8th ; recovery October 21 st. Has been in a cubicle in the private ward. It is not possible to establish clearly the source of infection in this case.

30. R. A., male attendant, aged thirty. Has been engaged in the asylum since September 10th, 1895; beginning of illness October 9th ; recovery November 18 th. This patient worked in the fields over which foecal matter was spread. He had permission to go out each evening from five to ten o'clook.

31. D., nurse, aged nineteen years. Appointed May 18th, 1898. Date of last leave of absence September 18th. Unable to work and sent to the nurses' infirmary on October 11th, 1898; temperature normal on November 20th. Was on duty from September 8 th to September 29 th in Division 4.

32. M. F., male attendant, aged twenty-seven years. Appointed June 20th, 189\%. Beginning of illness October 14th; recovery November 9th. Was attached to Division 7. Attended the inmates engaged on the fields. Was on duty from September 25th to October 5th in the male attendants' sickroom, which already had enteric fever patients in it.

32. R. E., female patient. Admitted October 28th, 1897. Belonged to Division 2. She was sent to the infirmary of Division 7 on the appearance of the first symptoms on October 16th; rash October 17 th. Died November 27th.

34. G. I., maile attendant, aged twenty-nine years. Appointed March 6th, 1895. Beginning of illness October 19th; termination November 23rd. Assisted in dispensary, and slept in a room adjoining it. Was on duty from September 17 th to Oetober 8 th in the male attendants' infirmary. He was generally free to go out from five to ten $\mathrm{p} . \mathrm{m}$.

35. M. A., male attendant. Engaged in asylum since June 20, 1898. Taken ill November 6 ; sent to hospital November 12; discharged at end of November. Employed in Division 7. Like so many of his colleagues, he took charge of inmates engaged in the fields or gardens.

Adding up the cases, we find there were attacked-18 female inmates, 1 male inmate, 7 female attendants, and 9 male attendants. Of the 18 first-named, 1 case was suffering from enteric fever on admission, and the origin of another's illness was undetermined. Subdivided according to the division in which these 18 cases were located, it appears that-

In Division 3 (clinical wards) there were 6 cases among 38 inmates, of whom 18 slept usually in the infirmary or sick ward.

In Division 4 there were 3 cases among 66 inmates, of whom 20 slept in the infirmary.

In Division 7 there were 7 cases among 81 inmates, of whom 20 slept in the infirmary on the ground-floor.

In the small private ward adjoining the clinical infirmary there were 2 cases (Nos. 13 and 29). The number of inmates varied. 
The first case arising within the asylum was that of the female patient $P$., but how she received the infection can only be conjectured. She had been in the infirmary of Division 7 from the beginning of the year 1897, and the first symptoms of enteric fever appeared on June 29, 1898. In Division 7 the sick ward is on the first floor, above the dormitory and day rooms. It must be noted that the inmates often slept in the infirmary even when the state of their health did not necessitate their doing so. In this connection attention has also to be directed to the fact that the inmates assisted the asylum attendants in their daily duties, of which one was the carrying of the stools of the patients to the ground-floor, where the closets (les lieux d'aisance) were placed. These two circumstances probably played an important part in the dissemination of the disease.

The discovery of Case 1 was shortly after followed by Cases 2,8 , $15,16,18,25$, and 27 in the same division. Case 33 does not properly belong to this series.

In Division 4 the first case (No. 6) observed was a woman who was ill on admission on August 18th. She remained in this division about a week, when she was transferred to the infirmary of Division 7. Subsequently three cases appeared in Division 4, on September 10th, 16th, and 23rd respectively. In this division also persons in the infirmary were not at all isolated from the other inmates, but there was this difference, that the infirmary was on the ground level, and the dormitories on the first floor. The inmates assisted the attendants in the same way as in Division 7.

In Division 3 the first case (No. 7) was detected on August 19th. The patient attacked had been in the Division 7 infirmary up to August 9th, and in all probability was infected there. Following this were cases $11,12,13$, and 21 .

The only ease observed among the male inmates was that of a. man who belonged to Division 8 , which is near the infirmary in which were treated the male attendants who were attacked. Moreover, he had been in frequent contact with them, and had even assisted on several occasions in the work of this infirmary.

The private ward in which two cases occurred (on September 1st. and October 6th) was reserved as a place for isolating paying patients. Such inmates received numerous visits from their friends, and food of all kinds may be sent in to them; it is therefore only with great reserve that we attribute the origin of the two eases which occurred here to personal infection.

Dealing now with the attendants, we find that seven males and nine females were attacked. Some difficulty exists in tracing the: 
exact origin of each case, as it was found that the attendants were, as a rule, not strictly attached to any one section, but were liable to be sent on duty in any part of the asylum. It was necessary, therefore, to ascertain where and for what period each one was engaged for some time prior to the development of the disease. Thus, Nurse G. S. (Case 3) had been on night duty in Division 7 for the fortnight just before she was taken ill. Another nurse, G. M. (Case 9), had been on duty from July 7th to August 5th in Division 4. She had to take to her bed on August 15, and similar circumstances were found in connection with the other nurses affected.

Two out of four men employed in the laundry were attacked, and these had specially to attend to the disinfection and cleansing of the linen belonging to the enteric patients. These cases point strongly to direct infection communicated in the discharge of their duties. It is cossible, of course, that they may have been infected outside the asylum, as they had days or evenings off duty, but the former explanation is the more likely.

The question arose as to the precise method by which infection was communicated: was it through the water supply being contaminated, or bý personal contact, direct or indirect?

The water supply at first sight appeared feasible, as an analysis of the water had been made by M. Gabriel Roux, the Director of the Lyons Municipal Laboratory. With the exception of Divisions 3 and 4, the inmates drank the water without previous sterilization, and the bacteriological analysis showed that the water was not fit for drinking purposes, from the number and character of the organisms it contained. Divisions 3 and 4 each had a Chamberland filter acting under pressure. Each filter discharged into a glass vessel, and on October 17 th the water taken from one of these vessels was found to contain 1,480 bacteria per cubic centimetre, two of them being liquefying organisms. There were many Coli bacilli present, from which circumstance the conclusion may be drawn that the Chamberland filter when used continuously requires cleansing from time to time and examination to insure that the connections are secure.

The arguments against the water theory were that in each division only patients resident or sleeping in the infirmaries were attacked, that only those in certain divisions were affected, that the epidemic did not develop suddenly, and that many were not attacked at once.

The theory was also advanced that the method adopted at this asylum of spreading the fæcal matter on the fields might be the 
cause of the outbreak. It should be noted, however, that men only were employed in the fields, that only one male inmate was attacked, and he had been assisting the male attendants in their ward duties. The attendants who accompanied the inmates to the fields and gardens did not take any active part in the work, their duty being to supervise. Yet it was the attendants, and not the inmates, who were attacked. This theory may therefore be dismissed. The possibility of infection being carried from the fields to the wards may also be disregarded. These fields are near the male wing, in which only one case occurred, and furthest from the female section, in which were most of the cases. The suggestion that the disease was spread by the use of vegetables manured with freal matter is not tenable either, as both the male and female inmates had vegetables from the same source; yet the outbreak was practically confined to the female side and those connected therewith.

When once the disease was introduced among the women, the conditions were such that the opportunities for infection were frequent. Inmates seem to have been sent into the infirmaries or sick wards on the slightest pretext. These wards were incompletely isolated, or, rather, we should say, communication with them was easy and constant. The method of removing the discharges of the patients appears to have been a very bad one; the regular attendants might be expected to take proper precautions, but it is hardly likely that the insane inmates who assisted them would do so. The attendants themselves were apparently without training in this branch of nursing, and therefore did not appreciate the danger to which they were exposed. We have no hesitation in attributing the cause of this epidemic to the want of care in dealing with the discharges of the patients.

Some useful conclusions may be drawn from a consideration of the series of cases given above. From the rarity of such epidemics, we are of opinion that the isolation of enteric patients is not absolutely necessary, if sufficient attention be given to certain hygienic precautions. It is necessary to insist on a scrupulous cleanliness being practised by those who have charge of enteric fever patients.

In our opinion inmates of asylums should not be allowed to assist the regular nurses. In this instance, as in some other asylums and hospitals, the defects in the general design of the building and in construction tended largely to the spread of the disease in this outbreak. Establishments like these resemble towns in which infections maladies have opportunities of spreading, but, on the other hand, prophylaxis is more easily attainable. It is only necessary to see that the elementary laws of health are complied 
with, and that cleanliness is enforced in regard to closets, night commodes, etc. Systematic disinfection of all objects used by enteric patients must be insisted upon.

As regards the Bron Asylum, we consider it requisite that a block be constructed to serve as an isolation pavilion. By the provision of such a block the infirmaries in each block could be kept for their proper use, viz., for the infirm, and such inmates who from their habits require special surveillance.

x Revue de Médecine, Angust 10th, 1898.

2 'Ueber Typhus Infection in Spitälern.' Wurzburg, 1885.

Diagnosis of RöTheLN.-Henry Koplik, of New York City, read a paper on "Rötheln: a Distinct Affection apart from Measles and Scarlatina, and its Differentiation from these Exanthemata." Rötheln has been donbted as an entity by some writers, but it can be proved to be such. It resembles measles, and is often mistaken for that disease. The rash appears on the face as a papular rash of deep rose-colour-as a rule, discrete, with crescentic outline. It spreads rapidly over the body, its appearance on the buttocks and thighs being regarded of diagnostic importance. In from a few hours to a day it fades. A real desquamation has never been established by Koplik. Unlike measles, rötheln is not a disease of the mucous membranes, and the cough, coryza, etc., of measles are never seen. The conjunctiva is injected, as in grip, but there is no photophobia. Children do not generally complain of the tonsils, which are injected, but adults do. As to the soft and hard palates, streaks and spots of eruption have been reported as ocourring in these locations during the disease. He has also observed this in epidemics, but the point emphasized is that these spots are absolutely not characteristic of rötheln, and hence of no diagnostic importance. The red spots with bluish-white centre, characteristic of measles, are absent, so the buceal mucous membrane is of negative diagnostic value. There may be no temperature-rise in rötheln. If there is a rise, it is generally at the onset of the disease, whether the eruption be out or not. The temperature may drop while the eruption is still present. A study of the lymph-nodes was made in twelve cases. The glands of the neck, axilla, and groin were distinctly enlarged. In rare cases of measles this also occurs, but so rarely as to make them of diagnostic importance in rötheln. This enlargement of glands often persists after the eruption has disappeared, and sometimes lasts for weeks. The spleen is not enlarged. In discussing this paper, Griffith said he had repeatedly seen desquamation in cases of rötheln. He does not find the temperature charts characteristic; although the glands are enlarged more than in measles, the cervical glands are often enlarged in the latter, and are found if looked for. Dr. Koplik said that he ruled out the cervical glands when making the diagnosis of rötheln, referring only to those of the axillæe and groin, which are diagnostic. He has never seen severe complications with the disease. He isolates cases, letting the children run in the street as soon as the rash disappears in summer, but keeping them indoors for a week in winter.-Philadelphia Medical Journal. 